\title{
Analysis of Academic Meetings Using Meeting Proceedings Publications
}

\author{
Thomas M. Krueger \\ Texas A\&M University Kingsville
}

The future of the academic meetings is highly dependent upon their perceived quality and impact on member's career. In an age of tight travel budgets, the sustainability of academic associations is even more dependent upon the annual meetings' ability to service member needs to share research, incubate ideas for future research, and network with colleagues. One measure of the annual meeting's ability to service its membership is the quality of its proceedings issues. This report examines the annual Proceedings of the Academy of Finance's over its first fifteen years in terms of authors, employers, and topics. Both recent participation and authorship trends are examined. Information will help academic administrators and authors gain fresh insight to this type of intellectual contribution. Furthermore, readers who are members of other professional organizations can put their association's proceedings publication into perspective.

\section{INTRODUCTION}

Virtually all professional associations have an annual meeting at which research is shared and collegial relationships are renewed, thereby targeting the long-term sustainability of the organization. Many organizations publish a written report of these gatherings which may include meeting minutes, lists of officers, and research presented by attendees. These proceedings are likely to be an accurate gauge of the health of the organization. Supporting this contention, Hurst et al. (1998) finds a high correlation in the perceived value of professional conferences and their proceedings editions.

The 2017 edition of the Proceedings of the Academy of Finance (hereafter AofF Proceedings) is the fifteenth edition to be published in conjunction with the annual meeting of the Academy of Finance. During the 2003-2017 period, the annual Proceedings have been edited by Thomas Krueger, first from the University of Wisconsin-La Crosse and since 2011 from Texas A\&M University - Kingsville. In total, there have been 383 contributions to the literature, stretching across 1708 pages. In recognition of the AofF Proceedings reaching its crystal anniversary, it is worthwhile to study this publication in detail and thereby gain insight to both the annual meeting of the Academy of Finance and the Academy itself. This article summarizes information regarding the authors, authors' employers and AACSB affiliation of the employers. Information regarding the finance topics in AofF Proceedings articles is also provided. This information is of value to both the Academy of Finance membership as a means to gauge the value of this annual publication and to employers trying to assess the value of the contributions made employees.

The remainder of this paper has three components. First, there is a literature review concerning association publications. Next there is a discussion of the Academy of Finance. Finally, this report presents valuable statistics characterizing the AofF Proceedings' first fifteen years. Through this 
endeavor, individuals at all levels of academia will have a clearer picture of the value of professional organizations and their publications.

\section{LITERATURE REVIEW}

In order to maintain their vitality and relevance virtually all academic associations, both inside and outside business, hold annual meetings. Many of these have a proceedings issue, produced in-house by one or two members of the organization. Examples of proceedings issues within finance organizations include:

Academy of Financial Services Conference Proceedings

Proceedings of the Annual Meeting on Pacific Basin Finance

Proceedings of the Annual Meeting of the Eastern Finance Association

Proceedings of the Midwest Finance Association

Proceedings of the Southwest Finance Association

Proceedings are also frequently published by third parties. Springer Publishing, the 175-year old publisher of many finance journals, for instance, publishes the first two proceedings in the following list. The third proceedings is published by the international institute of Social And Economic Sciences. Meanwhile, the last listed proceedings listed is produced by the Institute for Business and Finance Research.

Contemporary Trends and Challenges in Finance

New Trends in Finance and Accounting

Proceedings of the Economics and Finance Conference

Global Conference on Business and Finance Proceedings

There has been very little research examining the function and utility of conference attendance and proceedings publication. The author was unable to find a studious, careful review of the articles published within proceedings issues within finance, or almost any business discipline. The exception to this general observation is the marketing discipline, where the quality of conference programs and proceedings is examined within the Atlantic Marketing Association (i.e., Glascoff et. al. (1997)) Southern Marketing Association (i.e., Swift, et. al. 1998) and Winter Educator's Conference of the American Marketing Association (i.e., Jones et. al. (1988)).

Other research that is available is either related to meetings or to specific journals themselves. Analysis for instance has been done of presentations at the annual meetings of the American Real Estate Society (Johnson, Roulac, and Followill (1996)), Academy of Finance (Ebeid and Johnson (1994) and Johnson and Philpot (2007)), Financial Management Association (i.e., Egginton, Van Ness, and Van Ness (2013), and seven finance meetings simultaneously (Petry, 1981).

There has been history of questionnaires regarding the value of academic conferences leading back to Widing, Brown, and Luke (1989), who surveyed deans, department chairs, and faculty members. All agreed that conference participation played a role in the professional development of faculty. Authorship in national proceedings issues was ranked fourth in relative importance, while publication in regional proceedings was ranked tenth in relative importance. However, the importance of proceedings may have declined recently, as exemplified by Lewis and Kerr's (2012) proposed questionnaire regarding academic conferences. While the open-ended questions lend themselves to discussing the perceived value of conference proceedings, there is no specific question (across 41 items) in Lewis and Kerr's survey that directly asks for an assessment of conference-related publications.

Much more analysis has been done regarding journals, with some of this being relevant for the current study. Information regarding the authorship, author's degree-granting institution, and employer for the first forty years of the Journal of Finance captured information on 1788 authors, from 116 doctoral degree-granting institutions, currently working at 444 different institutions (Heck, Cooley, and Hubbard, 1986). After twenty more years, expanding the sample from 1946-2006, Heck and Cooley, (2008)) report 
that Journal of Finance authorship was up to 3,276 authors. Expanding their focus, Heck and Cooley (2009) examined 26 finance journals, concluding that 17,601 authors had participated, while not judging the quality of any individual journal. Chung and Cox (2001), and more recently Alderson, Saporoschenko, and Nasseh (2009), find a similar listing of prominent journals and continued citation of many articles as was originally noted by Alexander and Mabry (1994) in the past century. Like Professor Heck and Cooley's initial manuscripts, however, this study focuses on a single finance publication.

Researchers over time (i.e., Petry (1988) Hudson (1996), Sutter and Kocher (2004)) have observed a trend towards co-authorship. Brown, Chang, and Chen (2011) note that the trend in co-authorship is upward and consistently higher for the top three finance journals. Specifically, over the 1990-2004 period, the percentage of co-authorship rose from 55 percent to 70 percent in non-top tier journals and from 63 percent to 75 percent in top tier journals. Brown, Chang, and Chen ascribe the difference to the belief that publishing in top journals requires more work. This research will examine whether the same trend is occurring in proceedings publications. We address the co-authorship issue by examining the number of items authored by individual authors and those authored on an adjusted basis. For instance, on a threeauthor paper, the each author would be credited with one third of an article on an adjusted basis.

University-based analysis is examined by Dyl and Lilly (1985), Barry (1990), Fogarty and Ruhl (1997), and Jones and Roberts (2005). The latter authors plus Czinkota (2000) also address the larger issue of geographic dispersion of authors, both on a state and nation basis. Regionalizing the state issue, Fields and Swayne (1991), report a significant increase in the research produced by southern schools. An array of potential authorship characteristics worthy of study, including gender, years in academia, age, and present position, are presented by Polonsky and Whitelaw (2006). Svensson and Wood (2007) add ethnocentricity issues including the geographic locations of dual-authored manuscript. Unfortunately, many of these author-specific pieces of information are hard to obtain, leaving the current analysis with a study of authorship by university and geographic location.

Another way to assess journals is in terms of author concentration. For instance, Spake and Harmon (1998) examine the percentage of publication pages produced by the top 4 and top 8 contributing institutions. They find that the top four institutions contributed 19 percent of all articles, with 31 percent coming from the top eight institutions. They further analyze the percentage of authors producing over six to versus a single contribution. A similar analytic process will be applied in this study.

Talking about concentration, the information below includes data related to the concentration of the Proceedings of the Academy of Finance regarding various finance topics. Similar distributions have been done for Accounting (i.e., Weber and Stevenson, 1981), and economics (Allen and Kau, (1991)).

Delivering and monitoring quality has become all the more important in an era of tight travel budget, leading Griffin, Malone, and Cooper (2005) to question whether they are headed towards extinction. Given the lack of active recruiting at this spring meeting, the sustainability of the Academy of Finance is even more dependent upon the annual meetings' ability to service member needs to share research, incubate ideas for future research (see, for instance, Rittichainuwat, Beck and Lalopa (2000), Severt et al. (2006), and Eke (2011)), and network with other finance faculty members (i.e., McCarthy et. al (2004)). While the meeting's proceedings is like "icing on a cake," it provides insight to the content and quality of the conference itself.

\section{Academy of Finance}

The Academy of Finance traces its origin back to the 1987 meeting of the Midwest Business Administration Association (now MBAA International), when six finance instructors decided to reconstitute an academic finance association at MBAA. Earlier, in 1985, the Midwest Finance Association began meeting separately from MBAA. Johnson and Philpot (2007) report that other components of MBAA continued hosting papers on finance related topics. By 1989, the new association had reached the 50 members needed for inclusion as an official member of MBAA. While the new association was initially referred to as the Midwest Academy of Finance and Insurance (MAFI), at the 2000 meeting a decision was made to reduce the name to the Academy of Finance. 
A primary goal of the Academy of Finance has been to support member efforts to disseminate research findings. From 1988 until 2002, the Academy published the Midwest Review of Finance and Insurance. In 2003, and in conjunction with the organization's name change, the journal became the Journal of the Academy of Finance. Simultaneously, the Proceedings of the Academy of Finance grew out of concern that the Journal of the Academy of Finance was being viewed as simply a compendium of the reports presented at the organization's annual meeting. Paper accepted for presentation at the meeting permitted research inclusion in the Proceedings issue, while inclusion in the Journal of the Academy of Finance required presented papers to pass a second round of double-blind peer review.

In 2003, the Academy of Finance further improved the professionalism of its journal by allowing external manuscripts to be included in its publication. Authors no longer had to attend and present at the annual meeting of the Academy of Finance to be considered for publication. Shortly, thereafter, in order to highlight this change in publication requirements and further disassociate the journal from the annual meeting of the Academy of Finance, the name of the association's journal was changed to the Journal of Finance Issues. Meanwhile, the AofF Proceedings remained as the key representative of research completed and presented by meeting participants.

One implicit reason for initially conducting this research was to increase the visibility of Aof $F$ Proceedings among members of the Academy of Finance. Danielson and Delorme (1976) list journal length and prestige of editor's university as being the two most important variables in this regard. They suggest that associations limit the billing for copies and submissions to them in order to build a clientele. In the case of the AofF Proceedings, submission is free and a copy only costs $\$ 15$ in a jump drive format. In addition, many editions are downloadable at the Academy of Finance website.

\section{FINDINGS}

Intellectual contributions

TABLE 1

KEY CHARACTERISTICS OF THE PROCEEDINGS OF THE ACADEMY OF FINANCE: 2003-2017

\begin{tabular}{|l|c|c|c|c|c|}
\hline & Total Pages & Full Papers & Summaries & Authors & Institutions \\
\hline Total & 1708 & 108 & 274 & 598 & 403 \\
\hline Mean & 113.9 & 7.2 & 18.3 & 39.9 & 26.9 \\
\hline Median & 117 & 6 & 16 & 18 & 39 \\
\hline Maximum & 164 & 16 & 33 & 39 & 31 \\
\hline Minimum & 13 & 0 & 0 & 6 & 18 \\
\hline Standard Deviation & 34.9 & 4.2 & 10.5 & 16.3 & 10.9 \\
\hline
\end{tabular}

In total, intellectual contributions appearing in the AofF Proceedings can be found on 1708 pages, as exhibited in the first column of Table 1 . The mean and median are relatively close, at about 115 pages. However, the range in pages has been quite large, running from 24 to 164 pages. Figure 1 help one find out that the height of page production occurred in 2009, while the trough occurred in 2012. Dividing the page length in each year by the number of intellectual contributions, we find that the average length of a contribution was 4.8 pages in 2009 and 2.0 pages in 2012. Given that meeting submissions are during the fall of the year prior to each meeting, the actual timing of the impact of the financial crisis and travel budget cut would be 2008 and 2011. One potential reason for this variation is that the 2007-2009 financial crisis generated above average research interest while the impact of the financial crisis on university budgets was being felt in 2011 . 
One potentially confounding aspect of the analysis of annual meetings is that annual meetings may move from city to city, which may result in logistics-related reasons for differences in participation. Airport issues do not play a role when it comes to the AofF Proceedings, because MBAA-International is always held in Chicago. However, during this study the annual meeting moved from the Palmer House Hilton in downtown Chicago to the Drake Hotel on the north side of downtown Chicago and back again. The move to the Drake Hotel occurred in 2007, while the move back again occurred in 2014. Checking Figure 1, the reader can see that there can be an appreciable change in the number of total pages in those years when a conference first goes to a new location. The total number of pages increased by 23.7 (i.e., or 19.8 percent), compared to the three previous years in 2007, when the MBAA-International conference moved to the Drake Hotel. In 2014, when the MBAA-International Conference returned to the Palmer House Hilton, the total number of pages rose by 34.3, or 29.9 percent, relative to the average over the prior three years.

\section{FIGURE 1 TOTAL PAGES}

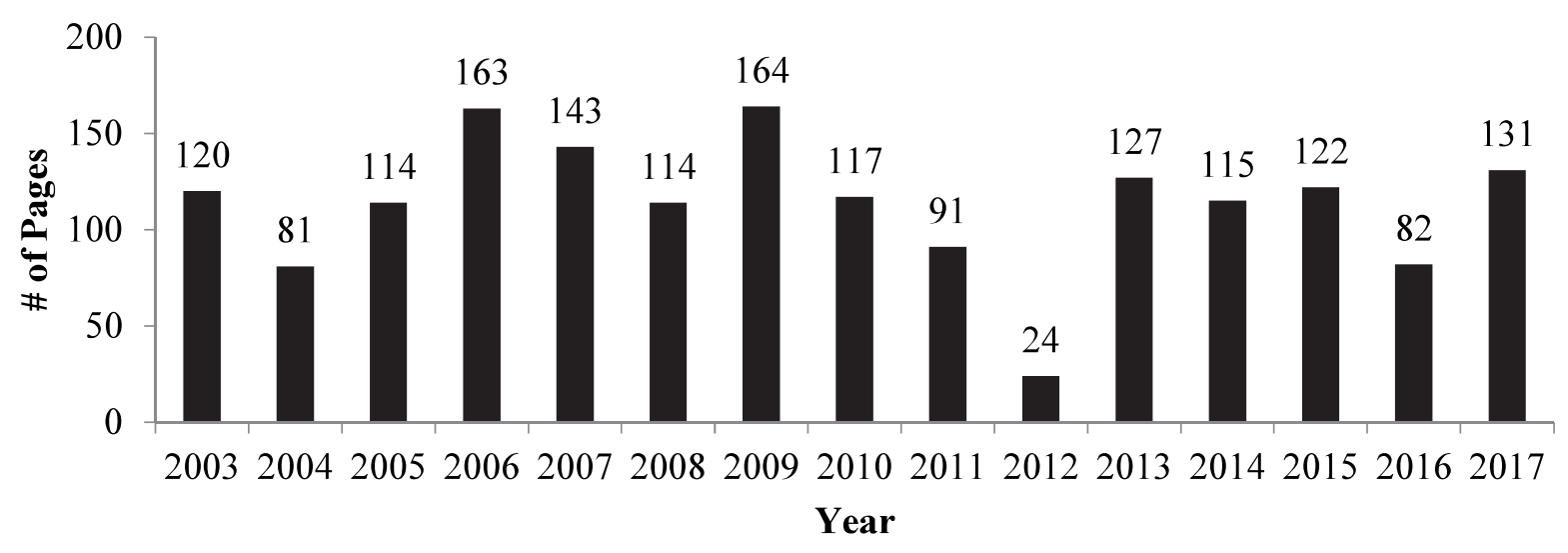

The AofF Proceedings has published a total of 382 intellectual contributions, 108 of which have been full papers and 274 research summaries. As shown in the second column, of Table 1, in the average year there have been seven full papers. However, there has been a wide range of from 13 intellectual contributions in the first year of the AofF Proceedings' existence, to 40 intellectual contributions in 2006. Figure 2 is a visual illustration of the intellectual contributions during the first fifteen years. After a twoyear start, we can see that there was relatively high participation from 2006 through 2011. The bars in Figure 2 then drop by approximately fifty percent of their previous height. 


\section{FIGURE 2 \\ INTELLECTUAL CONTRIBUTIONS ACROSS THE YEARS}

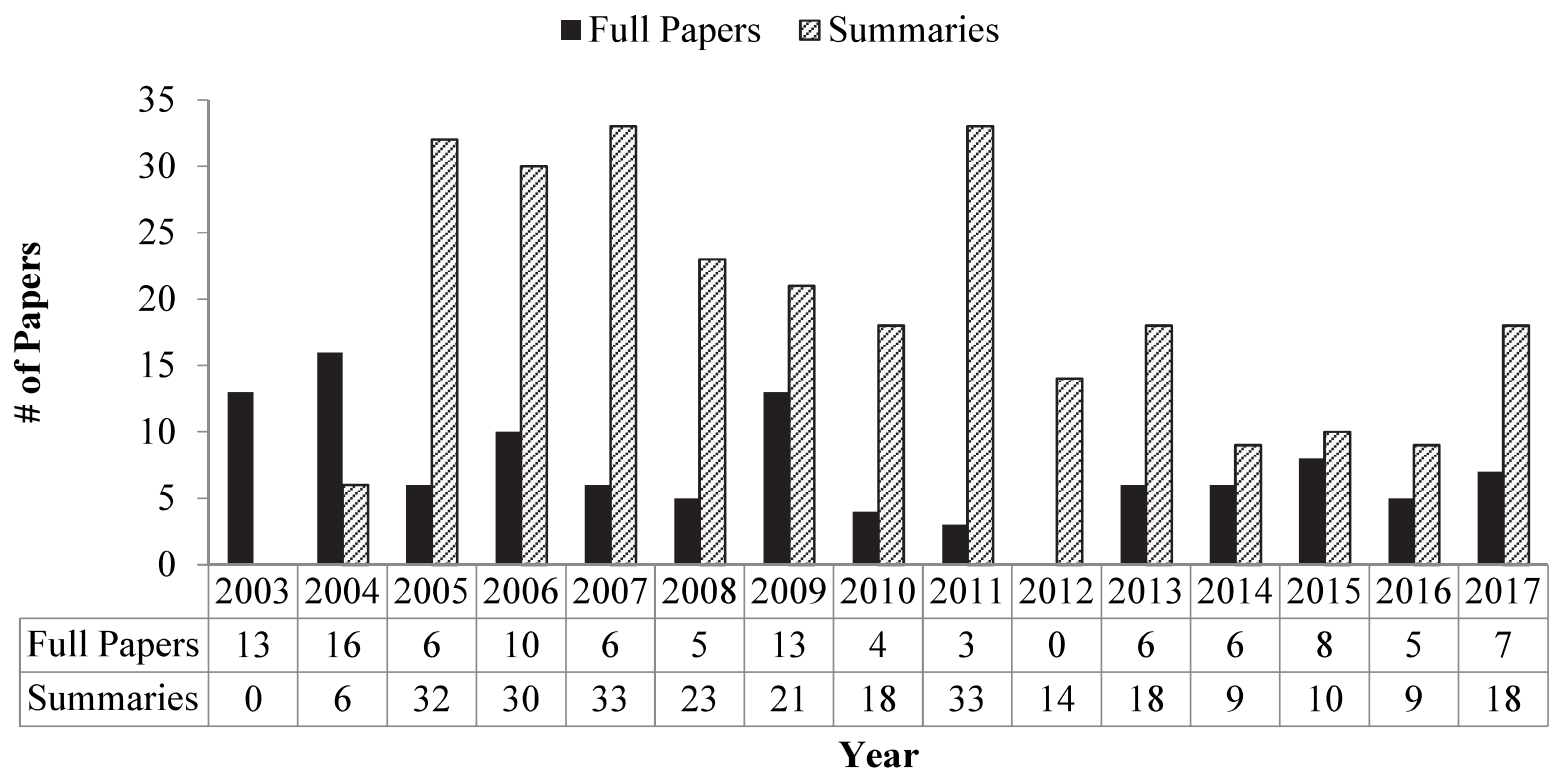

Authors have their choice of including either full papers or summaries in the AofF Proceedings. Across time there have been approximately 2.5 times as many summaries as full papers. In the first year, 2003 , only full papers were included. In contrast, only research summaries appeared in 2012. Excluding these unique years and the second year of the AofF Proceedings' existence, Figure 2 shows the persistent domination of researcher preference for only including summaries in the conference's publication. The reason for this preference is likely to be their desire to have research appear in publications that are blind refereed publications.

Examining the findings presented so far across five-year sub-periods, one can witness to interesting dichotomy of phenomenon occurring. One is the relative decline in the use of AofF Proceedings to publish intellectual contributions, with 152 intellectual contributions in the first five years, 134 in the second five years, and 97 in the most recent five years. Nonetheless, the average number of pages has stayed relatively constant, averaging 124 pages in the first five years, 102 in the second five years, and 115 in the most recent five years. One can deduce that the average page length per intellectual contribution has increased. In fact, the average page length has increased from 4.1 pages during the first five years to 5.9 pages during the most recent time period.

\section{Tracks}

Participation at the annual meeting of the Academy of Finance is open to all areas of finance and as its official mouthpiece so is the AofF Proceedings. Therefore the 382 intellectual contributions were spread across the tracks into which they fit. The largest single track is Investments (I), at 93 items. If one adds the 26 contributions in the personal finance (PF) track, which can have information on retirement options but frequently is focused on specific securities, the total reaches 119 . The second most common subject matter is Corporate Finance (CF). Three tracks have very similar participation levels, with there being 50 global finance (GF) papers, 49 financial markets (FM) papers, and 48 education in finance (EF) papers. About one third of the financial markets papers have been specifically about bank-related issues. The two smallest tracks are real estate, at 14 intellectual contributions, and risk management at 19 items, though 7 of these are related specifically to insurance topics. 


\section{FIGURE 3 \\ DISTRIBUTION OF TRACKS}

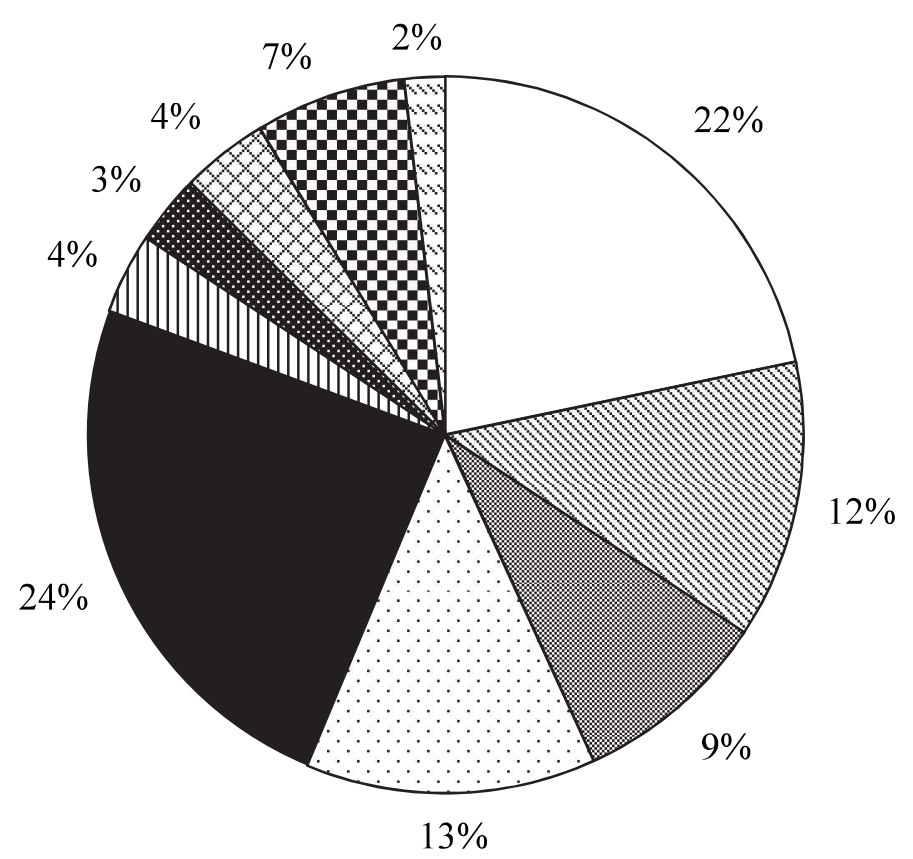

$\square$ Corporate Finance

Education Finance

圆 Financial Markets

$\square$ Global Finance

- Investments \& Portfolio

Management

प Real Estate

옹 Risk Management

[ Banking

Personal Finance

@ Insurance

The popularity of different tracks is illustrated in terms of the percentage of all 382 articles by Figure 3. Investments accounts for 24 percent of all research published in the AofF Proceedings. Two percent fewer, 22 percent, of the AofF Proceedings have been about corporate finance. Adding in the 7 percent of articles about personal finance and over half of all AofF Proceedings contributions have been accounted for by just a few tracks. Global finance and financial education are the focus of an additional 13 percent and 12 percent, respectively of the AofF Proceedings articles. Financial markets topics account for 9 percent of the articles, leaving the other tracks to account for the remaining 13 percent of the articles. 


\section{FIGURE 4 \\ TRACKS OVER TIME}

First Five Years

Second Five Years

Last Five Years

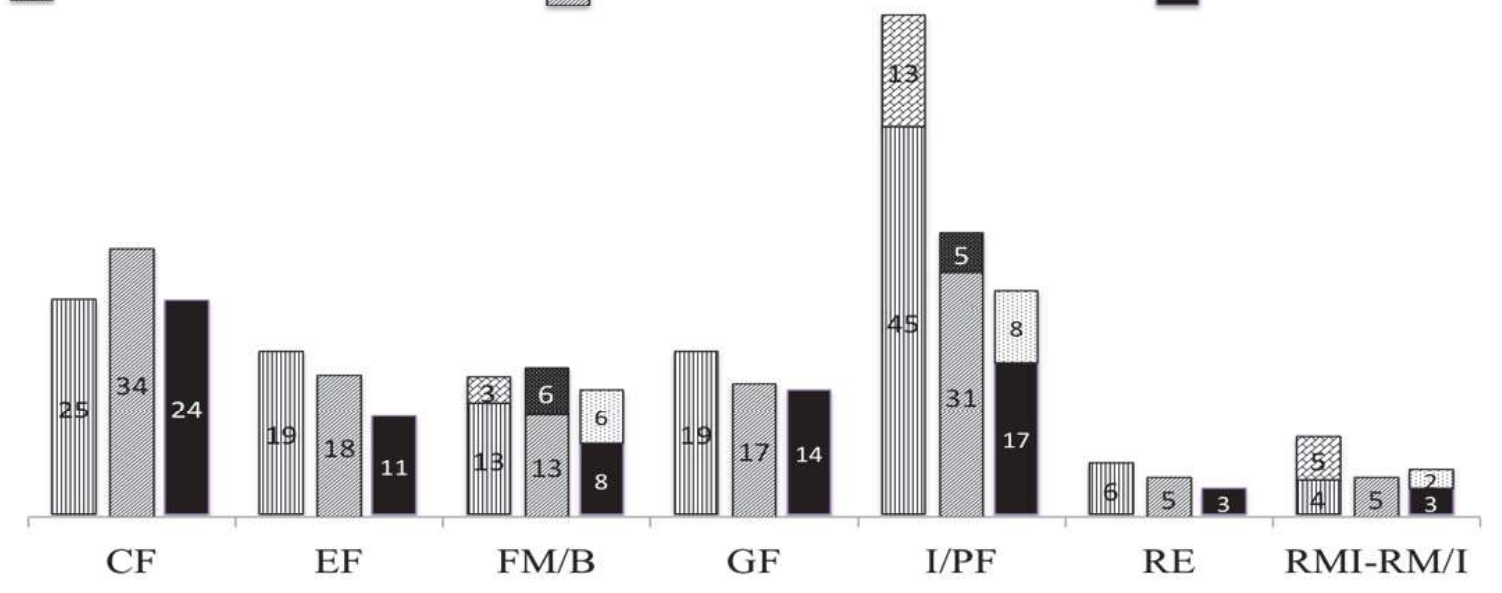

The change in focus of the Academy of Finance over the past fifteen years is illustrated by Figure 4. As noted above, the number of intellectual contributions has declined from 152 from 2003-2007 to 97 from 2013 to 2017, a 36 percent decline. Much of this drop can be attributed to investments-related research which is off 62.2 percent. Personal Finance research has also declined 38.4 percent. By contrast, corporate finance research has maintained its interest with a decline of only 4.0 percent. The only other large change is the 42.1 percent drop in finance education research.

\section{Authorship}

FIGURE 5

\section{AUTHORS}

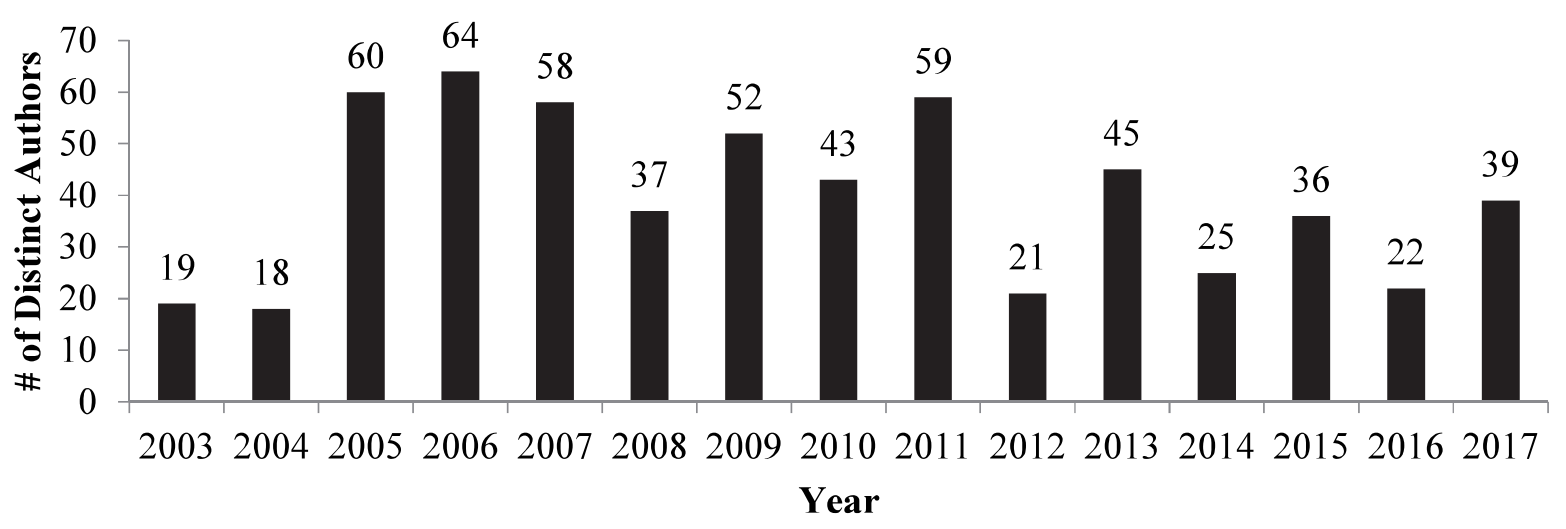

Excluding instances of multiple intellectual contributions in a given year, a total of 598 authors have participated in the writing of at least one of the 382 intellectual contributions. Across the fifteen years, there is little skewness in these values resulting in a mean and median of about 39 authors a year, as shown in column 4 of Table 1. As shown in Figure 5, the highest level of authorship occurred in 2006, when AofF Proceedings articles were penned by 64 unique authors. Authorship was up over threefold from 2004's 18 authors.

In recent years there has been a dramatic drop in the number of contributing authors. During the fiveyear $2003-2007$ period, there was an average of 43.8 authors. Over the next five-year timeframe there 
was a slight drop to an average of 42.4 authors per year. However, during the most recent $2013-2017$ five-year timeframe, 33.4 authors on average authored or co-authored an intellectual contribution.

TABLE 2

\section{MOST PRODUCTIVE AUTHORS}

\begin{tabular}{|c|c|c|c|}
\hline Name of Author & Total & Name of Author & Adjusted \\
\hline Thomas M. Krueger & 30 & Thomas M. Krueger & 18.24 \\
\hline John S. Bowdidge & 28 & John S. Bowdidge & 11.11 \\
\hline C. Edward Chang & 26 & C. Edward Chang & 10.62 \\
\hline George S. Swales & 23 & George S. Swales & 8.44 \\
\hline Mark A. Wrolstad & 15 & Raj K. Kohli & 7.83 \\
\hline Jamshid Mehran & 12 & Mark A. Wrolstad & 7.32 \\
\hline Robert Balik & 12. & Chien-Chih Peng & 7.00 \\
\hline K. Matthew Wong & 10 & Charles W. Johnson & 6.83 \\
\hline Raj K. Kohli & 9 & Robert Balik & 6.16 \\
\hline Chien-Chih Peng. & 8 & K. Matthew Wong & 6.00 \\
\hline Thomas Cooper & 8 & Jamshid Mehran & 5.49 \\
\hline Alex Faseruk & 7 & Kumoli Ramakrishnan & 4.00 \\
\hline Charles W. Johnson & 7 & Ashrafee Hossain & 2.99 \\
\hline John E. Patton & 7 & Thomas Cooper & 2.98 \\
\hline Rizwan Ali & 7 & Charles R. Rayhorn & 2.83 \\
\hline Ashrafee Hossain & 6 & John E. Patton & 2.82 \\
\hline Greg M. Lepak & 6 & Ingyu Chiou & 2.66 \\
\hline John Consler & 6 & Kent P. Ragan & 2.66 \\
\hline Sung C. Bae & 6 & Richard F. Belloff & 2.50 \\
\hline Charles R. Rayhorn & 5 & Greg M.Lepak & 2.49 \\
\hline Ingyu Chiou & 5 & Sung C. Bae & 2.49 \\
\hline Kent P. Ragan & 5 & Alex Faseruk & 2.31 \\
\hline Kumoli Ramakrishnan & 5 & Rizwan Ali & 2.23 \\
\hline Mudassar Hassan & 5 & John Consler & 1.99 \\
\hline Richard F. Belloff & 5 & Yuli Su & 1.99 \\
\hline Yuli Su & 5 & Mudassar Hassan & 1.57 \\
\hline
\end{tabular}

A list of the most productive authors is exhibited in Table 2. The left-hand side of this table reports author participation in terms of articles which they authored. For instance, the top author submitted thirty items, or an average of two per year. Four other authors submitted at least one item per year, on average. Twenty-six authors submitted at least five manuscripts, which is equivalent to an average of one every three years.

The right hand side of Table 2 presented adjusted articles totals. For instance, co-authors each would have half of the credit (i.e., 0.5 points) per article. All of the values on the right hand side of Table 2 are smaller than those on the left side of this table, meaning that each of the authors with at least five articles in the AofF Proceedings co-authored at least one paper. The smallest difference form the left to the right side of Table 2 is that of Charles Johnson, which experiences a drop from 7 articles to a 6.83 adjusted value. The largest drop is experienced by John Bowdidge, whose decline from 28 to 11.11, indicates that he did a large amount of coauthoring. 


\section{TABLE 3 AUTHOR TURNOVER NEW AND REPEAT AUTHOR PARTICIPATION RELATIVE TO PRIOR YEAR}

\begin{tabular}{|c|c|c|c|c|}
\hline Year & Prior Year Total & Repeat Authors & New Authors & Present Year Total \\
\hline 2004 & 19 & 5 & 25 & 30 \\
\hline 2005 & 30 & 9 & 51 & 60 \\
\hline 2006 & 60 & 16 & 48 & 64 \\
\hline 2007 & 65 & 17 & 42 & 59 \\
\hline 2008 & 59 & 19 & 19 & 38 \\
\hline 2009 & 38 & 10 & 42 & 52 \\
\hline 2010 & 52 & 15 & 26 & 41 \\
\hline 2011 & 41 & 13 & 46 & 59 \\
\hline 2012 & 59 & 7 & 12 & 19 \\
\hline 2013 & 19 & 7 & 38 & 45 \\
\hline 2014 & 45 & 8 & 18 & 26 \\
\hline 2015 & 26 & 9 & 26 & 35 \\
\hline 2016 & 35 & 7 & 15 & 22 \\
\hline 2017 & 22 & 4 & 35 & 39 \\
\hline
\end{tabular}

Sustainability requires new authors across time. In order to observe the extent to which authors are added Table 3 presents information on the number of repeat authors and new authors, which together equal the number of authors in a given year. For instance, in 2004, five authors carried over from 2003 and were joined by 25 new authors. The only year in which the number of repeat authors was not less than the number of new authors is 2008, when the number of repeat and new authors equaled 19. Approximately, 74 percent of each year's authors are new authors, suggesting that one way for a conference to grow is through the retention of prior year's authors. The new author density is fairly consistent, with 72.8 percent of the AofF Proceedings during the 2004-2008 period being authored by new writers, 73.6 percent during the 2009-2013 period being new authors, and 75.2 percent during the 2014-2017 being new authors.

A trend towards co-authorship is not evident in the Proceedings issues. On average, co-authorship occurs for about 67.1 percent of all AofF Proceedings items, which is very similar to the percentage reported by Brown, Chang, and Chen (2011) for non-top tied journals. However, unlike the 23 percent increase in coauthorship reported by Brown, Chang, and Chen, co-authorship in the AofF Proceedings is only up by 2.8 percent. During the first five years, 67.1 percent of AofF Proceedings articles were coauthored. Following a dip to 65.4 percent over the ensuing five years, during the most recent 20132017 period 68.7 percent of items were co-authored.

\section{Institutions}

When considered on a year-by-year basis, 403 institutions of higher education have been represented by authors of intellectual contributions in the AofF Proceedings, as shown in right column of Table 1. Comparison of the mean of 26.9 and median of 31, suggests that there that there is some negative skewness. In fact, the number of institutions has ranged widely from 11 to 44 . The early years had the lowest institutional representation, while 2011 had the highest institutional representation, as shown in Figure 6. There is some correlation between the number of authors found in Figure 5 and institutional representation, found in Figure 6. For instance, the three years with the most authors also have the three highest levels of institutional representation. 
FIGURE 6

\section{INSTITUTIONS}

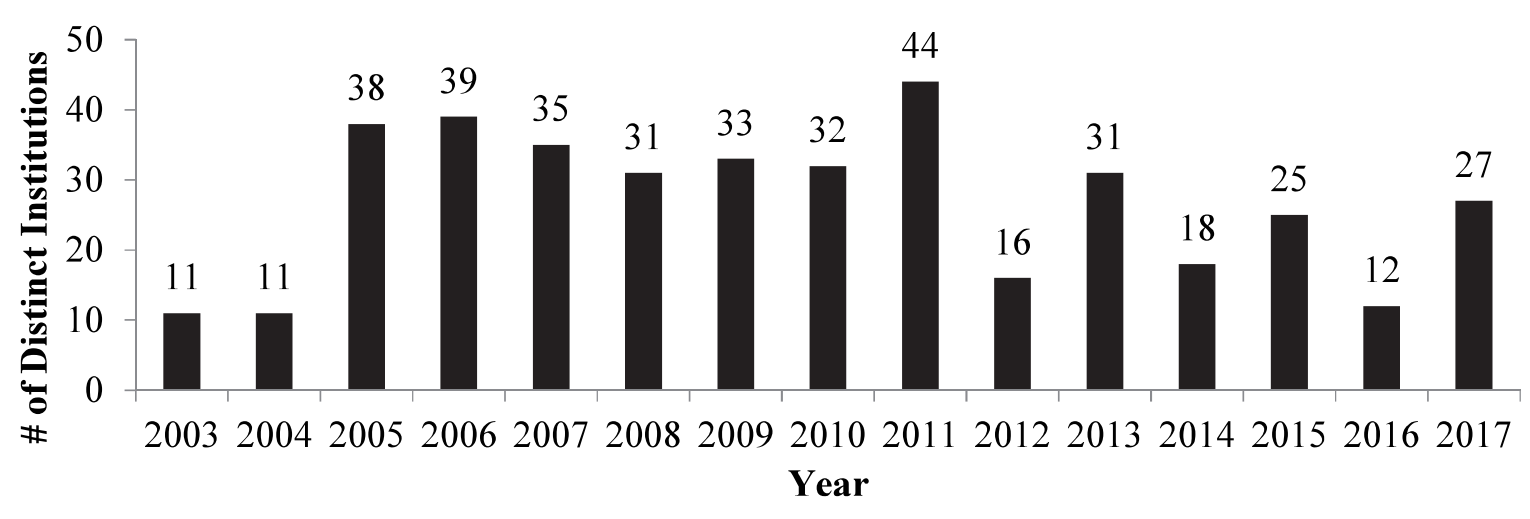

\begin{tabular}{|c|c|c|}
\hline Total Participating Institutions & 172 & \\
\hline AACSB Business Accredited & 104 & $60.47 \%$ \\
\hline AACSB Accounting Accredited & 34 & $19.77 \%$ \\
\hline
\end{tabular}

Institutions may appear in multiple years and multiple authors may come from a single institution, so another way to examine the institution data is in terms of number of institutions that have appeared across time. As shown on the bottom of Figure 6, 172 unique institutions have employed authors of intellectual contributions appearing in the AofF Proceedings. Sixty percent of these are AACSB-accredited schools and twenty percent are institutions with an Accounting program accredited by AACSB-International.

Another way to examine institutions is in terms of the number of employees which authored papers. As seen in Table 4, the most prolific institution in terms of publication in the AofF Proceedings is Missouri State University, with 39 authored papers, 14 of which come from the period when this school was Southwest Missouri State University. Approximately two thirds as many author/articles have been penned at Memorial University (a Newfoundland school) at 24, and Indiana University South Bend at 23. At least five different articles have been authored by faculty at twenty-nine institutions.

TABLE 4

INSTITUTIONS

INSTITUTIONS WITH FIVE OR MORE CONTRIBUTING AUTHORS Author count was adjusted so that there were no duplicate author count in the same year

\begin{tabular}{|c|c|c|c|}
\hline Missouri State University & 39 & University of Wisconsin - Green Bay & 9 \\
\hline Memorial University & 24 & Western Michigan University & 9 \\
\hline Indiana University South Bend & 23 & Michigan Tech University & 8 \\
\hline Le Moyne College & 16 & Morehead State University & 8 \\
\hline Winona State University & 16 & North Carolina A\&T University & 8 \\
\hline Western Illinois University & 15 & San Francisco State University & 8 \\
\hline Northern Michigan University & 12 & St. John's University & 8 \\
\hline Southeast Missouri State University & 12 & Bradley University & 7 \\
\hline University of Wisconsin - Oshkosh & 11 & California State University & 7 \\
\hline Baker College & 10 & Duquesne University & 6 \\
\hline Eastern Illinois University & 10 & Hillsdale College & 6 \\
\hline University of Wisconsin - La Crosse & 10 & Bowling Green State University & 5 \\
\hline Texas A\&M University - Kingsville & 9 & Truman State University & 5 \\
\hline University of Lahore & 9 & University of South Dakota & 5 \\
\hline
\end{tabular}


Information regarding institutional location, within and outside the United States is presented on the left and right, respectively, in Table 5.

TABLE 5

HOME LOCATIONS OF CONFERENCE AUTHORS

Location counts was adjusted so that there were no duplicate authors in the same year

\begin{tabular}{|c|c|c|c|c|c|c|c|c|}
\hline Location & Frequency & Percent & Location & Frequency & Percent & \multicolumn{3}{|c|}{ * Locations outside the US } \\
\hline AK & 3 & 0.52 & MO & 66 & 11.40 & Location & Frequency & Percent \\
\hline $\mathrm{AL}$ & 5 & 0.86 & MS & 1. & 0.17 & Australia & 4 & 0.69 \\
\hline $\mathrm{AR}$ & 10 & 1.73 & $\mathrm{NC}$ & 13 & 2.25 & Brazil & 1 & 0.17 \\
\hline CA & 27 & 4.66 & ND & 1. & 0.17 & Canada & 25 & 4.32 \\
\hline $\mathrm{CO}$ & 4 & 0.69 & $\mathrm{NE}$ & 3 & 0.52 & Chile & 1 & 0.17 \\
\hline $\mathrm{CT}$ & 2 & 0.35 & $\mathrm{NJ}$ & 1 & 0.17 & China & 8 & 1.38 \\
\hline DE & 2. & 0.35 & NJ & 2. & 0.35 & Dubai & 1 & 0.17 \\
\hline FL & 2 & 0.35 & NY & 33 & 5.70 & France & 4 & 0.69 \\
\hline GA & 7 & 1.21 & $\mathrm{OH}$ & 10 & 1.73 & Georgia & 1 & 0.17 \\
\hline IA & 3. & 0.52 & OR & 2 & 0.35 & Korea & 7 & 1.21 \\
\hline IL & 5. & 0.86 & PA & 3 & 0.52 & Netherlands & 1 & 0.17 \\
\hline IL & 68 & 11.74 & $\mathrm{PA}$ & 11 & 1.90 & Pakistan & 9 & 1.55 \\
\hline $\mathrm{IN}$ & 25 & 4.32 & RI & 2 & 0.35 & Rwanda & 1 & 0.17 \\
\hline $\mathrm{KS}$ & 1. & 0.17 & $\mathrm{SC}$ & 2 & 0.35 & Taiwan & 7 & 1.21 \\
\hline KY & 12 & 2.07 & SD & 6 & 1.04 & Thailand & 1 & 0.17 \\
\hline LA & 1. & 0.17 & $\mathrm{TN}$ & 2 & 0.35 & Turkey & 5 & 0.86 \\
\hline LA & 2. & 0.35 & TX & 22 & 3.80 & \multirow[t]{8}{*}{$\begin{array}{l}\text { United } \\
\text { Kingdom }\end{array}$} & \multirow[t]{8}{*}{2} & \multirow[t]{8}{*}{0.35} \\
\hline MA & 4 & 0.69 & UT & 1. & 0.17 & & & \\
\hline $\mathrm{MD}$ & 2. & 0.35 & VA & 3 & 0.52 & & & \\
\hline $\mathrm{ME}$ & 1. & 0.17 & WA & 10 & 1.73 & & & \\
\hline MI & 53 & 9.15 & $\mathrm{DC}$ & 1. & 0.17 & & & \\
\hline $\mathrm{MN}$ & 22 & 3.80 & WI & 45 & 7.77 & & & \\
\hline \multicolumn{4}{|c|}{ * Countries outside US } & 78 & 13.47 & & & \\
\hline \multicolumn{4}{|l|}{\begin{tabular}{|l|} 
Total \\
\end{tabular}} & 579 & 100 & & & \\
\hline
\end{tabular}

Authors have come from 43 states and the District of Columbia. As one might expect given that the annual Academy of Finance meeting is held in Chicago, geographic density is concentrated in this vicinity. The state with the most authors is Illinois at 68 articles, which is only two ahead of the 66 articles contributed by authors employed by Missouri institutions. Over seven percent of articles also originated in two adjacent states, Michigan at 53 articles and Wisconsin at 45 articles. Authors have also come from sixteen foreign nations. Thirteen percent of the AofF Proceedings articles come from outside the United States with 25 of these coming from Canada. Over three percent of articles were penned in Asia, with Chinese authors contributing 8 articles, Korean authors contributing 7 articles, and Taiwanese authors also contributing 7 articles. The AofF Proceedings paints a picture of the Academy of Finance being a regional meeting with several authors from across the globe. 


\section{CONCLUSION}

The role and importance of academic conferences appears to be diminishing in the eyes of administrators providing travel support. Conference support is all the more challenging for a spring conference, which is normally well after the employment market has found its equilibrium for the coming academic year. In order to shed light on the dynamic changes in conference participation and effort put forth by authors, this study examined the fifteen-year history of the Academy of Finance's annual proceedings. Authors have their choice of submitting either a complete paper or a two-page summary to the AofF Proceedings upon having their proposal for presentation at the annual spring meeting accepted.

Despite the apparent importance of professional meetings, very little has been published about their Proceedings issues, making this a new and fertile area for research. The findings demonstrate the value of the Proceedings as a contribution to research by Academy of Finance membership. Over its first fifteen years, the AofF Proceedings has published 382 intellectual publications, with 108 of these being full papers. Participation has dropped in recent years, led by declines in the Investments and Finance Education tracks. Findings show that much of the decline has arisen from not retaining author interest from year to year and not effectively reaching out to other parts of the country or globe.

There are many ways to expand upon this research. The most obvious is to conduct the same sort of analysis for another conference's proceedings publication. This benchmark could be compared to proceedings produced by another finance association or another field in or out of business. Surveying participants regarding their perception of the importance of various aspects of a conference (i.e., location, hotel amenities, scheduling, etc.) and assessment of how an association's meeting is addressing these preferences would also be informative.

\section{ACKNOWLEDGEMENT}

The author would like to thank Ms. Crystal Le, Graduate Student at Texas A\&M UniversityKingsville, for her assistance in this project.

\section{REFERENCES}

Alderson, M. J., Saporoschenko, A., \& Nasseh, A. (2009). The Relative Significance of Finance Journals, Authors and Articles: An Update. Advances in Financial Education, 2009.

Alexander, J. C., \& Mabry, R. H. (1994). Relative Significance of journals, authors, and articles cited in financial research. Journal of Finance, 49 (2), 97-712.

Allen, M. T., \& Kau, J. B. (1991). Contributing authors and institutions to the Journal of Urban Economics: 1974-1989. Journal of Urban Economics, 30, 373-384.

Barry, T. E. (1990). Publication productivity in the three leading US advertising journals: Inaugural issues through 1988. Journal of Advertising, 19(1), 52-60.

Brown, C. L., Chang, K. C., \& Chen, C. R. (2011). First-author conditions: Evidence from finance journal coauthorship. Applied Economics, 43 (25), 3687-3697. DOI: $10.1080 / 00036841003689739$

Chung, K. H., \& Cox, R. A. K. (2001). Citation patterns in the finance literature. Financial Management, 30 (3), 99-118.

Czinkota, M. R. (2000). International information cross-fertilization in marketing: An empirical assessment. European Journal of Marketing, 24(11), 1305-1314.

Danielson, A. L., \& Delorme, C. D. (1996). Some empirical evidence on the variables associated with the ranking of economics journals. Southern Economic Journal, 43(2), 1149-1160.

Dyl, E. A., \& Lilly, M S. (1995). A note on institutional contributions to the accounting literature. Accounting, Organizations and Society, 10 (2) 174-175.

Ebeid, F. J. \& Johnson, D. T. (1994). An analysis of papers presented at the Midwest Academy of Finance and Insurance: 1987 - 93. Midwest Review of Finance and Insurance, 8 (1), 1-9. 
Eiggenton, J. F., Van Ness, B. F., \& Van Ness, R. A. (2013). An Analysis of the FMA annual meetings: Presentation activity of institutions and individuals, 1996-2012. Journal of Applied Finance, 23(2), 132-145.

Eke, H. N. (2011). An empirical study of the impact of NLA conference attendance on librarians' professional development. PNLA Quarterly, 75 (4).

Fields, D. M., \& Swayne, L. E. (1991). Contributions of southern authors in major marketing publications. Journal of Business Research, 22, 33-45.

Fogarty, T. J., \& Ruhl, J. M. (1997). Institutional antecedents of accounting faculty research productivity: A LISREL study of the" best and brightest". Issues in Accounting Education, 12(1), 27.

Glascoff, D. W., Grant, J., Jones, K. C., and Swift, C. O. (1997). Longitudinal findings about the perceived quality of professional organizational association conferences with special attention to the role and direction of the Atlantic Marketing Association's conference. Proceedings of the Atlantic Marketing Association, October, 303-312.

Griffin, L., Malone, C., \& Cooper, W. (2005). Academic professional conferences: Targeted for extinction as we know them? Academy of Educational Leadership Journal, 9(3), 23-29.

Heck, J.L., Cooley, P. L., \& Hubbard, C. M. (1986). Contributing Authors and Institutions to the Journal of Finance: 1946-1985. The Journal of Finance, 41(5), 1129-1140.

Heck, J. L., \& Cooley, P. L. (2008). Sixty years of research leadership: contributing authors and institutions to the Journal of Finance. Review of Quantitative Finance and Accounting, 31, 287309.

Heck, J. L. and Cooley, P. L. (2009). Most Prolific Authors in the Finance Literature: 1959-2008 (March 8, 2009). Downloaded on May 22, 2017 at SSRN: https://ssrn.com/abstract=1355675. http://dx.doi.org/10.2139/ssrn.1355675

Hudson, J. (1996). Trends in multi-authored papers in economics. Journal of Economic Perspectives, 10: $153-158$.

Hurst, C., Owens, C., Johns, K. C., Glascoff, D. W., \& Grant, J. (1998). The quality of conference programs and the value of conference proceedings: Future direction for the Academy of Marketing Science. Proceedings of the 1998 Academy of Marketing Science Annual Conference, edited by Ford, J. B., \& Honeycutt, E. D., Springer: Norfolk, Virginia, pages 68-74.

Johnson, D. T. \& Philpot, J. (2007). History of the Academy of Finance Building for the future, 19872007. Academy of Finance Website.

Johnson, L. L., Roulac, S.E., and Followill, R. A. (1996). American Real Estate Society annual meeting paper presentations: The first decade (1985-1994). Journal of Real Estate Research, 12 (2), 1995-2007.

Jones, K. C., Swift, C. O., Glascoff, D., \& Grant, J. W. (1988). "Perceived quality of AMA Winter Educator's Conference programs and proceedings: Findings and future directions." AMA Winter Educators Conference Proceedings, 9, July, 365-374.

Jones, M. J., \& Roberts, R. (2005). International publishing patterns: an investigation of leading UK and US accounting and finance journals. Journal of Business Finance \& Accounting, 32(5 $\square 6), 1107$ 1140 .

Lewis, C., \& Kerr, G. M. (2012). Towards the development of an evaluation questionnaire for academic conferences. Event Management, 16 (1), 11-23.

McCarthy, J., McDonald, D., Soroczak, S., Nguyen, D., \& Rashid, A. (2004). Augmenting the social space of an academic conference. Computer Supported Cooperative Work, 6(3), 39-48.

Petry, Glenn H. (1981). A history and analysis of scholarly papers presented at seven academic finance associations from 1939 through 1980. Financial Management, 10 (2), 93-102

Petry, Glee H. (1981). A statistical analysis of worldwide coauthorship relationships in scholarly journals of business. Journal of Economics and Business, 40 (2), 93-104.

Polonsky M. J., \& Whitelaw, P. (2006). A multi-dimensional examination of marketing journal rankings by North American academics. Marketing Education Review, 16 (3), 59-72. 
Rittichainuwat, B. N., Beck, J., \& Lolopa, J. (2001). Understanding motivations, inhibitors, and facilitators of association members in attending conferences. Journal of Convention \& Exhibition Management, 3 (3), 45-62.

Severt, D., Wang, Y., Chen, P., \& Breiter, D. (2006). Examining the motivation, perceived performance, and behavioural intentions of convention attendees: Evidence from a regional conference. Tourism Management, 28, 399-408.

Spake, D. F., \& Harmon, S. K. (1998). Institutional and individual research productivity: A comparison of alternative approaches. Marketing Education Review, 8(3), 67-77.

Sutter, M., \& Kocher, M. (2004). Patterns of coauthorship among economics departments in the USA. Applied Economics, 36 (4), 327-333.

Svensson, G., \& Wood, G. (2007). Ethnocentricity of academic marketing journals: A study of authors, reviewers, editorial boards, and editors. Marketing Intelligence \& Planning, 25 (3), 252-270.

Swift, C. O., Glascoff, D. W., Jones, K. C., and Grant, J. (1998). Faculty perceptions of academic marketing conferences and proceedings. Marketing Education Review, 8 (3), 79-88.

Weber, R. P., \& Stevenson, W. C. (1981). Evaluations of accounting journal and department quality. Accounting Review, 56 (3), 596-612.

Widing, R. E., Browne, G., \& Luke, R.H. (1989). The value of activity leading to knowledge development in marketing" in King, R. L. ed., Marketing: Positioning for the 1990s. Southern Marketing Association, 211-216. 